\title{
Gas Phase Activation of Methane Molecule with Lead Benzene Dication Complex Ion, $\left[\mathrm{Pb}(\text { Benzene })_{2}\right]^{2+}$
}

\author{
Joseph K. Koka ${ }^{1,2}$ \\ ${ }^{1}$ School of Chemistry, University of Nottingham, Nottingham, United Kingdom \\ ${ }^{2}$ Department of Chemistry, School of Physical Sciences, University of Cape Coast, Cape Coast, Ghana \\ Email: jkoka1@ucc.edu.gh
}

How to cite this paper: Koka, J.K. (2019) Gas Phase Activation of Methane Molecule with Lead Benzene Dication Complex Ion, $\left.[\mathrm{Pb} \text { (Benzene })_{2}\right]^{2+}$. Materials Sciences and Applications, 10, 105-117.

https://doi.org/10.4236/msa.2019.102009

Received: November 17, 2018

Accepted: January 26, 2019

Published: January 29, 2019

Copyright $\odot 2019$ by author(s) and Scientific Research Publishing Inc. This work is licensed under the Creative Commons Attribution International License (CC BY 4.0).

http://creativecommons.org/licenses/by/4.0/

\begin{abstract}
Motivated by the search for ways of a more efficient usage of the ubiquitous, and unexploited resources of methane, recent progress in the gas-phase activation of methane by metal dication complex ion is discussed. The gas phase theoretical and experimental analysis on $\left.[\mathrm{Pb} \text { (Benzene })_{2}\right]^{2+}$ was conducted. The $\left[\mathrm{Pb}(\text { Benzene })_{2}\right]^{2+}$ complex ions were prepared using a combination of the pick-up technique and high energy electron impact, and then held in a cold ion trap. Excitation with tuneable UV radiation resulted in the formation of $\left[\mathrm{Pb}(\text { Benzene })_{2}\left(\mathrm{H}_{2} \mathrm{O}\right)\right]^{2+}, \quad\left[\mathrm{Pb}(\text { Benzene })_{2}\left(\mathrm{H}_{2} \mathrm{O}\right)_{2}\right]^{2+}, \quad[\mathrm{Pb}(\text { Benzene })]^{+}, \mathrm{Pb}^{+}$and Benzene $^{+}$ions when the experimental results were analysed. The two optimised geometries of $\left[\mathrm{Pb}(\text { Benzene })_{2}\right]^{2+}$ namely the $\mathrm{C}_{2 \mathrm{~V}}$ eclipse and $\mathrm{C}_{2}$ staggered were observed. Methane activation of $\left[\mathrm{Pb}(\text { Benzene })_{2}\right]^{2+}$ complex ion yielded $\left[\mathrm{Pb}(\text { Benzene })_{2}(\mathrm{Me})\right]^{2+}$. $\left.[\mathrm{Pb} \text { (Benzene })_{2}\left(\mathrm{H}_{2} \mathrm{O}\right)(\mathrm{Me})_{2}\right]^{2+}$,

$\left.[\mathrm{Pb} \text { (Benzene })_{2}\left(\mathrm{H}_{2} \mathrm{O}\right)(\mathrm{Me})\right]^{2+}$, $\left[\mathrm{PbBenzene}(\mathrm{Me})_{3}\right]^{2+}$ and $[\mathrm{Pb}$ (Benzene $\left.)(\mathrm{Me})\right]^{2+}$. The PEC calculated binding energy of methane to lead benzene dication complex ion was approximately $25.45 \%$ higher than the value recorded on DFT calculation. This difference was due to the charge differences on the lead metal centre. While the actual calculated charge on the $\mathrm{Pb}$ metal in the optimised geometry was 1.68 the charge of +2 on the $\mathrm{Pb}$ metal was considered in the PEC calculation.
\end{abstract}

\section{Keywords}

Lead, Benzene, Binding Energy, Methane Activation, Dication Complex Ion, Density Functional Calculations, Potential Energy Curve

\section{Introduction}

Methane concentrations had increased globally from 722 parts per billion 
(ppb) in pre-industrial times by a factor of 2.5 to $1800 \mathrm{ppb}$ [1] and currently to 1850.5 ppb, July 2018 [2].

Although the amount of methane emissions is five times less than those of $\mathrm{CO}_{2}$, they are similarly problematic because methane can retain, approximately 23 times more heat than $\mathrm{CO}_{2}$ in the atmosphere [3]. A challenge for the future is the activation of methane and its conversion into more valuable feed stocks, because it would permit a much more efficient use of methane from either geological deposits or biogenic sources [1] into other valuable and/or environmentally friendly chemical compounds. Understanding of the nature of bonds in complexes can serve as a vehicle in the conversion of methane into a more valuable feedstock which will be of strategic importance in tropical chemistry where experiments in the gas phase can have a significant impact. Imagine a small plant that has methane and air as inputs where resources of methane could be used much more efficiently; for example, steam reforming converts methane into syngas [Equation (1)] from which methanol can be produced in a second step [Equation (2)]; or partial oxidation of methane according to Equation (3) to produce methanol as a liquid.

$$
\begin{aligned}
\mathrm{CH}_{4}+\mathrm{H}_{2} \mathrm{O} & \rightarrow \mathrm{CO}+3 \mathrm{H}_{2} \\
\mathrm{CO}+2 \mathrm{H}_{2} & \rightarrow \mathrm{CH}_{3} \mathrm{OH} \\
\mathrm{CH}_{4}+\mathrm{O}_{2} & \rightarrow \mathrm{CH}_{3} \mathrm{OH}
\end{aligned}
$$

Most biological processes are identified to involve heavy metals or their cations which usually act as poisons [2]. It is a well instituted fact that lead toxicity in particular is widely spread in nature from centuries [4] [5] [6] [7]. As a result of anthropogenic activities, lead is primarily dispersed throughout the environment in the form of particles in the air, and is removed by rain or gravitational settling. Plants and animals may have bioconcentrate lead $(\mathrm{Pb})$ which the general population may be exposed to in ambient air, foods, drinking water, soil and dust. Hence the detection of lead and the treating of lead poisoning in the environment [8] has attracted a wide-spread attention more importantly investigation into lead (II) complexes in the gas phase. In inorganic chemistry lead complexes play a vital role as intermediates in homogeneous catalysis as well the active bonding between metal cation and ligands play a key role in coordination chemistry [9].

To date, there are three major techniques for generation of metal ion ligand complexes in the gas phase namely laser vaporization, electrospray and the pickup technique. Extensive investigation into $\mathrm{Pb}^{2+}$ complexes using infrared, ultraviolet spectroscopy and mass spectrometry in both the liquid and gaseous phases abound. Burt et al. used mid-Infrared Multiple-Photon Dissociation (IRMPD) spectroscopy to determine the gas-phase structures of deprotonated $\mathrm{Pb}^{2+} / \mathrm{amino}$ acid complexes with and without a solvent molecule present [10]. Firdoussi et al. by the application of electrospray ionization in combination with tandem mass spectrometry characterised the glycosidic linkage of underivatised 
disaccharides by interaction with $\mathrm{Pb}^{2+}$ ions [11]. Further, Salpin et al. evidenced the formation of macrochelate forms and tautomerization of the uracil moiety by the application of tandem mass spectrometry and mid-IRMPD spectroscopy for the $\mathrm{Pb}^{2+} /$ uridine-5'-monophosphate complex [12]. The structure of the $\mathrm{Pb}^{2+}$-deprotonated 2'-deoxyguanosine-5'-monophos-phate (dGMP) complex, generated in the gas phase by electrospray ionization, was examined by combining tandem mass spectrometry, mid-infrared multiple-photon dissociation (IRMPD) spectroscopy and ion mobility in the gas phase [13]. Lead (II) complexes were synthesized with Schiff bases derived from 4-methoxybenzaldehyde and amino acids (tryptophan, phenylalanine, valine, isoleucine, methionine, histidine, alanine, cysteine, serine and aspartic acid). The ligands act as monobasic bidentate species and coordinate to the lead atom through the azomethine nitrogen and carboxylate oxygen atom [14]. Salpin and Tortajada had successfully use electrospray to syntheses $\mathrm{Pb}(\mathrm{II})$ compounds [15] [16] while Stace et al. indicated that the pickup technique appeared to be the only method capable of preparing $\mathrm{Pb}$ (II)-based complexes where the metal cation is associated with a very wide range of ligands, here the coordinating atoms used were oxygen, nitrogen, sulphur and phosphorus, together with complexes consisting of benzene and argon in association [17]. Using the pick-up technology with a cold ion trap mass spectrometer, our group recently recorded the state-resolved UV photofragmentation spectra of $\left.[\mathrm{Pb} \text { (benzene })_{2}\right]^{2+}[18]$.

\section{Experimental Section}

$\left[\mathrm{Pb}(\text { Benzene })_{2}\right]^{2+}$ ions were synthesised in the gas phase and their spectra recorded via UV photofragment spectroscopy within an ion trap mass spectrometer cooled to between $100-150 \mathrm{~K}$. A schematic diagram of the apparatus is shown in Figure 1. Neutral $\left[\mathrm{Pb}(\text { Benzene })_{n}\right]$ clusters were generated via the pickup technique [19], whereby argon carrier gas at a pressure of 130 psi was passed through a reservoir of benzene held at room temperature. The resultant

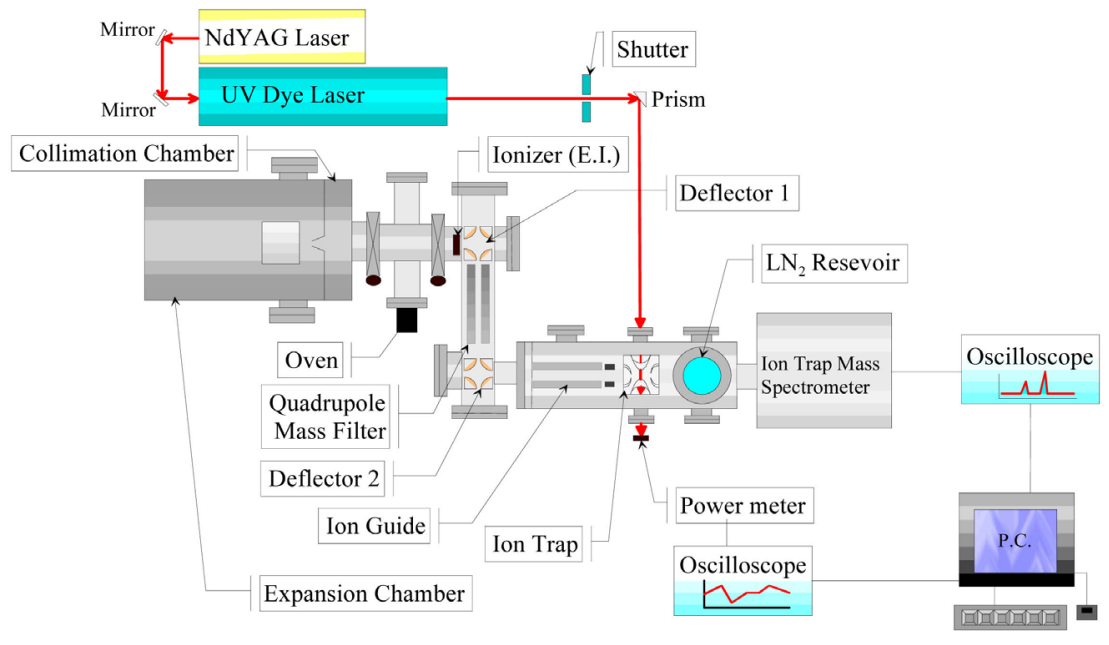

Figure 1. The diagram illustrating the experimental set up. 
mixture, containing approximately $1 \%$ benzene vapour, underwent supersonic expansion through a $50 \mathrm{~mm}$ diameter nozzle before passing through a $1 \mathrm{~mm}$ diameter skimmer.

The emerging beam of mixed argon/pyridine clusters then passed over the top of a Knudsen cell containing manganese chips heated to $1150^{\circ} \mathrm{C}$, which was sufficient to generate a metal vapour pressure of $10^{-3}$ to $10^{-2}$ mbar. Collisions between metal vapour and the mixed clusters generated neutral metal-containing clusters, which were then ionised by high energy electron impact $(100 \mathrm{eV})$ in the ion source of a quadrupole mass spectrometer (Extrel). From the mixture a doubly charged ions, $\left.[\mathrm{Pb} \text { (Benzene })_{2}\right]^{2+}$ was mass selected and directed by an ion guide into a Paul ion trap. The end caps of the latter were grounded and continuously cooled through direct contact with a liquid nitrogen reservoir. As a result, helium buffer gas $\left(5 \times 10^{-4}\right.$ mbar $)$ contained within the trap was also cooled and over a total trapping time of $1 \mathrm{~s}$, collisions between the helium and trapped ions led to a considerable reduction in the internal energy content of the latter [20]. Based on the observation of unimolecular decay by trapped ions, the internal temperature was thought to drop from $4500 \mathrm{~K}$ to somewhere in the range $100-150 \mathrm{~K}$. This cooling procedure has led to the appearance of discrete structure in the spectra (Figure 2).

To optimize the peak intensity of $\left[\mathrm{Pb}(\text { Benzene })_{2}\right]^{2+}$ the ion optical was effectively tuned to maximise the signal of the calculated target of the metal complex dication at $181.5 \mathrm{amu}$. In addition a sharp peak due to the parent ion picking up water from the background gas as it circulates within the trap was observed at $190.5 \mathrm{amu}$ (Figure 2).

The ions were irradiated with seven $10 \mathrm{~ns}$ pulses of tunable UV radiation from the frequency-doubled output of a Nd: YAG-pumped dye laser following a 300 ms collection and cooling period, before being ejected for mass analysis and signal averaging. This gave a total duty cycle of $1.0 \mathrm{~s}$ for each period of ion injection

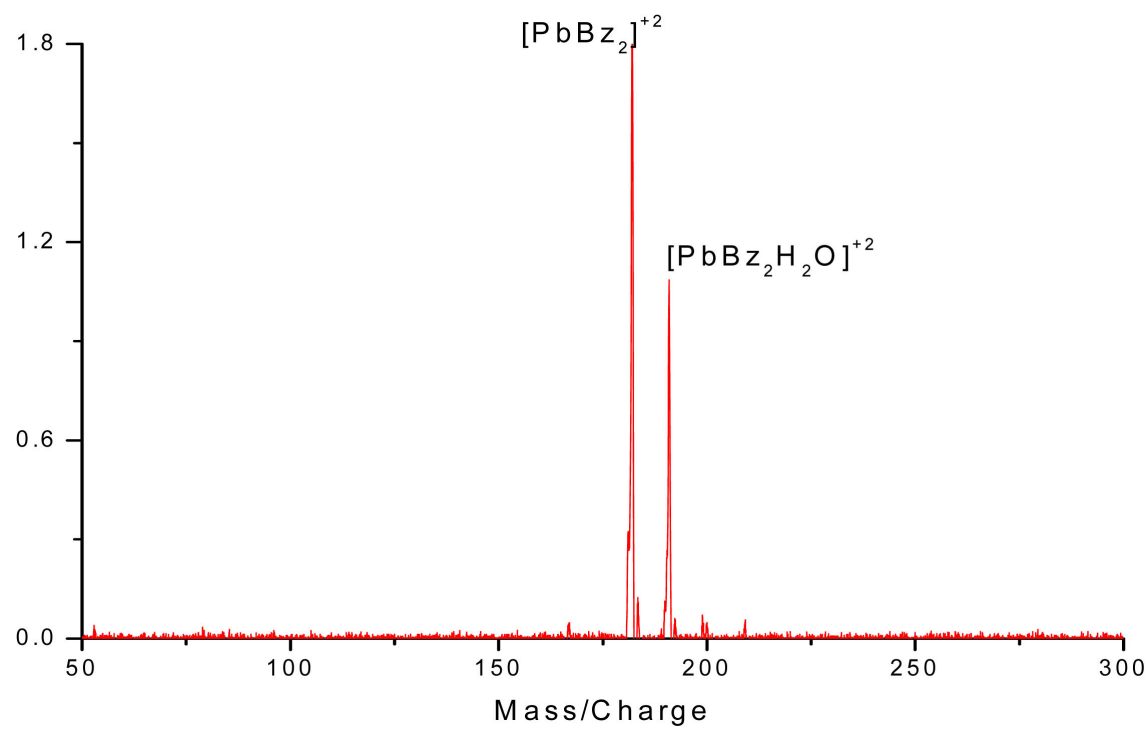

Figure 2. Mass spectrum of $\left[\mathrm{Pb}(\text { Benzene })_{2}\right]^{2+}$ at oven temperature of $890^{\circ} \mathrm{C}$. 
and excitation. Photon absorption led to fragmentation, and the intensities of the precursor and all fragment ions were monitored as a function of photon energy. The cycle of trapping and laser excitation was repeated 200 times to yield a photofragment mass.

Figure 3 denotes a typical photofragment mass spectrum of $\left[\mathrm{Pb}(\text { Benzene })_{2}\right]^{2+}$. Three parent ion peaks were identified $\left[\mathrm{Pb}(\text { Benzene })_{2}\right]^{2+}$ at $181.5 \mathrm{amu}$ the parent ions picking one and two molecule(s) of water from the background gas as it circulates within the trap forming $\left.[\mathrm{Pb} \text { (Benzene })_{2}\left(\mathrm{H}_{2} \mathrm{O}\right)\right]^{2+}$ at $190.5 \mathrm{amu}$ and $\left.[\mathrm{Pb} \text { (Benzene })_{2}\left(\mathrm{H}_{2} \mathrm{O}\right)_{2}\right]^{2+}$ at $199.5 \mathrm{amu}$ respectively. In addition, three photofragment peaks relating to the $[\mathrm{Pb} \text { (Benzene) }]^{+}$at $285 \mathrm{amu}, \mathrm{Pb}^{+}$at $207 \mathrm{amu}$ and Ben$z^{2} e^{+}$ions were also observed. Compared to the previous work at the same average photon energy of $45,355 \mathrm{~cm}^{-1}$ two additional distinct weak peaks of $[\mathrm{Pb}(\text { Benzene })]^{+}$and $\mathrm{Pb}^{+}$were observed in this current work [18].

Figure 4 presents the mass spectrum of methane activation at oven temperature of $890^{\circ} \mathrm{C}$. Four new distinct ion peaks were observed namely,

$\left[\mathrm{Pb}(\text { Benzene })_{2}\left(\mathrm{H}_{2} \mathrm{O}\right)(\mathrm{Me})_{2}\right]^{2+}=206.5 \mathrm{amu},\left[\mathrm{Pb}(\text { Benzene })_{2}\left(\mathrm{H}_{2} \mathrm{O}\right)(\mathrm{Me})\right]^{2+}=198.5$ amu, $\left[\mathrm{Pb}(\text { Benzene })(\mathrm{Me})_{3}\right]^{2+}=166.5 \mathrm{amu}$ and $[\mathrm{Pb}(\text { Benzene })(\mathrm{Me})]^{2+}=150.5 \mathrm{amu}$. The important point about the fragmentation mass spectrum is that even without inputting energy via the laser, the complex ions are also able to fragment via collision induced dissociation (CID).

A typical photofragmentation mass spectrum of the methane activation with $\left.[\mathrm{Pb} \text { (Benzene })_{2}\right]^{2+}$ under laser irradiation at wavelength of $42,283 \mathrm{~cm}^{-1}$ is shown in Figure 5. The spectra presented the parent fragment $\left[\mathrm{Pb}(\text { Benzene })_{2}\right]^{2+}$ at 181.5 amu; a characteristic photofragmentation route of losing a molecule of benzene ${ }^{+}$ resulting in the appearance of the lead monocation complexes $[\mathrm{Pb} \text { (Benzene) }]^{+}$ at $285 \mathrm{amu}$. The ability of the parent ion to pick a molecule of water to form $\left.[\mathrm{Pb} \text { (Benzene })_{2} \mathrm{H}_{2} \mathrm{O}\right]^{2+}$ was observed at $190.5 \mathrm{amu}$. In addition various metal benzene hydrated dication complex with methane molecule such as $\left[\mathrm{Pb}(\text { Benzene }){ }_{2} \mathrm{H}_{2} \mathrm{OCH}_{4}\right]^{2+}$

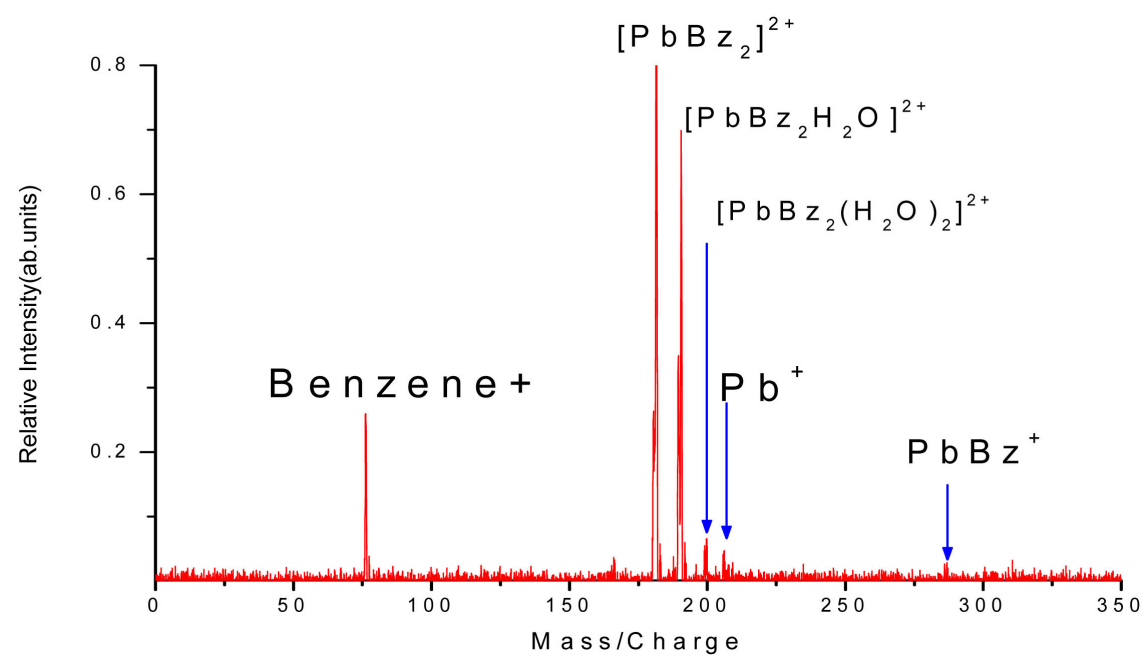

Figure 3. Photofragmentation Mass spectrum of $\left[\mathrm{Pb}(\text { benzene })_{2}\right]^{2+}$ by ion trap mass spectrometer recorded under laser irradiation at an average photon energy of $45,355 \mathrm{~cm}^{-1}$. 


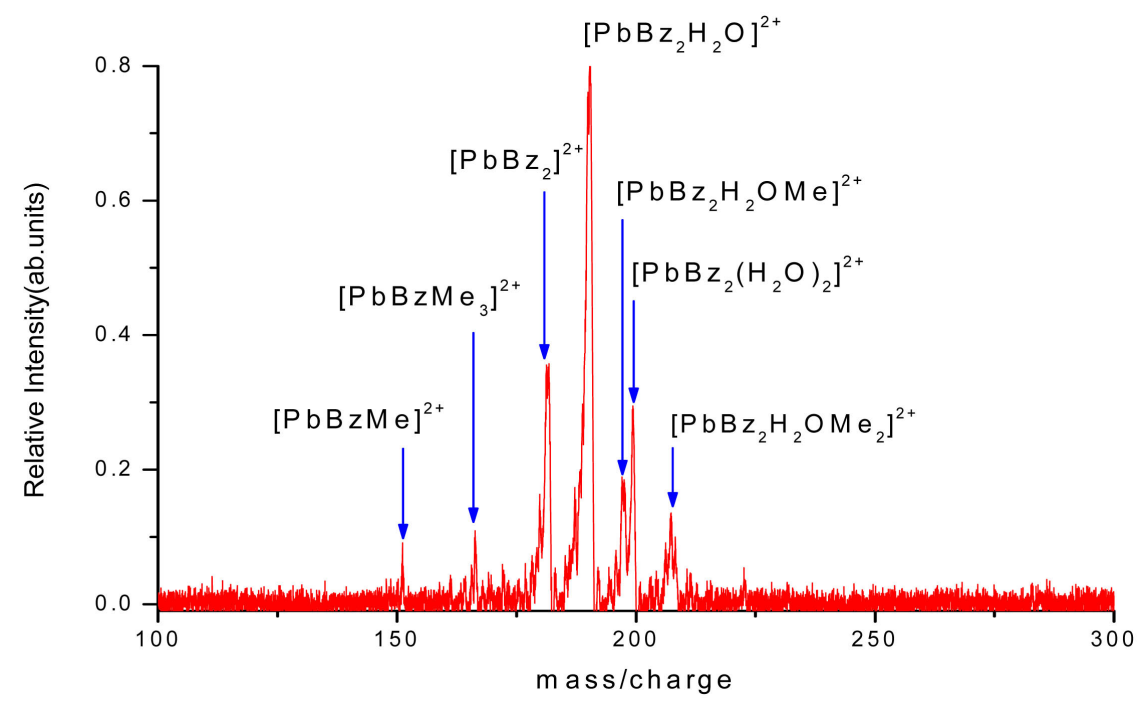

Figure 4. Collision induced dissociation mass spectrum of $\left[\mathrm{Pb}\left(\mathrm{C}_{6} \mathrm{H}_{6}\right)_{2} \mathrm{CH}_{4}\right]^{2+}$.

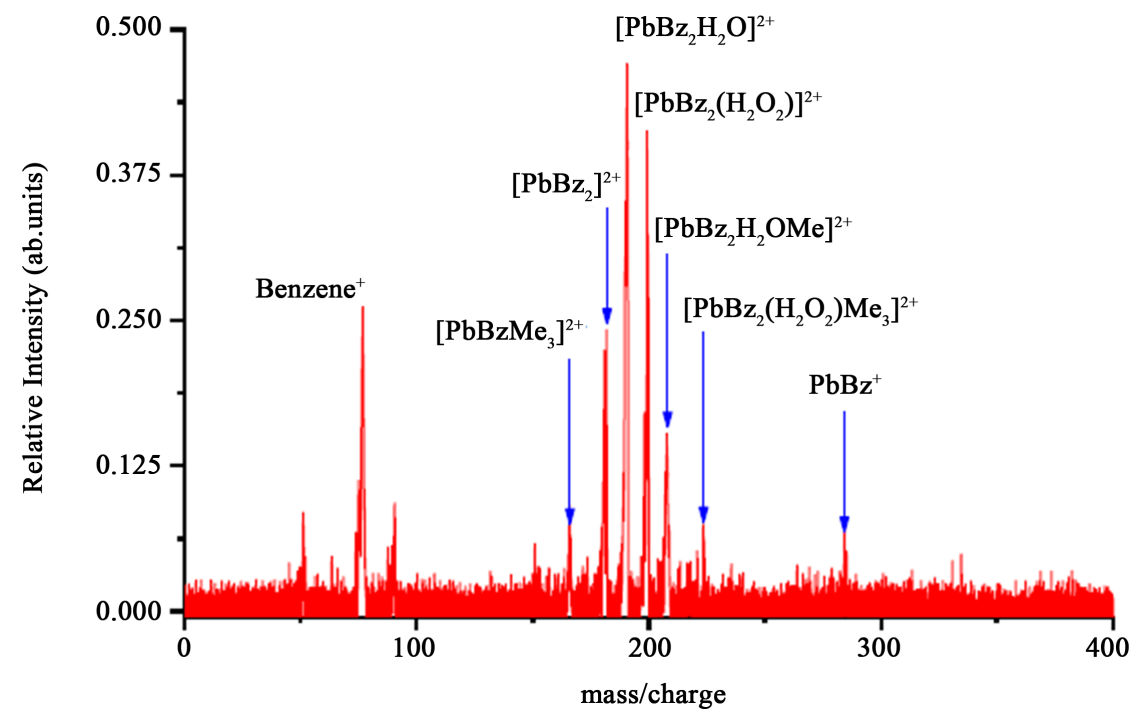

Figure 5. Photofragmentation Mass spectra $\left[\mathrm{Pb}\left(\text { Benzene) }{ }_{2} \mathrm{CH}_{4}\right]^{2+}\right.$ (Photon energy $=$ $\left.42,283 \mathrm{~cm}^{-1}\right)$.

at $198.5 \mathrm{amu},\left[\mathrm{Pb}(\text { Benzene })_{2}\left(\mathrm{H}_{2} \mathrm{O}\right)_{2}\left(\mathrm{CH}_{4}\right)\right]^{2+}$ at $207.5 \mathrm{amu}$, $\left.[\mathrm{Pb} \text { (Benzene })_{2}\left(\mathrm{H}_{2} \mathrm{O}\right)_{2}\left(\mathrm{CH}_{4}\right)_{2}\right]^{2+}$ at 215.5 amu and $\left.[\mathrm{Pb} \text { (Benzene })_{2}\left(\mathrm{H}_{2} \mathrm{O}\right)_{3}\left(\mathrm{CH}_{4}\right)\right]^{2+}$ at $216.5 \mathrm{amu}$ were identified. Comparing the nature of laser induced fragmentation (LIF) to CID (Figure 4 and Figure 5), it was observed that the peak intensities of the fragments in CID depreciated enabling the appearance of the daughter photofragments benzen $\mathrm{e}^{+}$and $[\mathrm{PbBenzene}]^{+}$with appreciably ion peak intensities in LIF.

\section{Photofragmentation of $\left[\mathrm{Pb}(\mathrm{BENZENE})_{2}\right]^{2+}$}

Photofragmentation of $\left.[\mathrm{Pb} \text { (Benzene })_{2}\right]^{2+}$ in the ion trap can occur in three possible reaction routes as illustrated below:

$$
\left[\mathrm{Pb}(\text { Benzene })_{2}\right]^{2+} \rightarrow \mathrm{Pb}^{2+}+2 \text { Benzene }
$$




$$
\begin{gathered}
{\left[\mathrm{Pb}(\text { Benzene })_{2}\right]^{2+} \rightarrow[\mathrm{Pb}(\text { Benzene })]^{+}+\text {Benzene }^{+}} \\
{\left[\mathrm{Pb}(\text { Benzene })_{2}\right]^{2+} \rightarrow[\mathrm{Pb}(\text { Benzene })]^{2+}+\text { Benzene }} \\
{\left[\mathrm{Pb}(\text { Benzene })_{2} \mathrm{CH}_{4}\right]^{2+} \rightarrow\left[\mathrm{Pb}(\text { Benzene })_{2}\right]^{2+}+\mathrm{CH}_{4}} \\
\left.\mathrm{~Pb}(\text { Benzene })_{2}\left(\mathrm{CH}_{4}\right)_{2}\right]^{2+} \rightarrow\left[\mathrm{Pb}(\text { Benzene })_{2} \mathrm{CH}_{4}\right]^{2+}+\mathrm{CH}_{4} \\
\left.\mathrm{~Pb}(\text { Benzene })_{2}\left(\mathrm{CH}_{4}\right)_{2}\right]^{2+} \rightarrow\left[\mathrm{Pb}(\text { Benzene })_{2}\right]^{2+}+2 \mathrm{CH}_{4} \\
{\left[\mathrm{~Pb}(\text { Benzene })_{2} \mathrm{CH}_{4} \mathrm{H}_{2} \mathrm{O}\right]^{2+} \rightarrow\left[\mathrm{Pb}(\text { Benzene })_{2} \mathrm{H}_{2} \mathrm{O}\right]^{2+}+\mathrm{CH}_{4}} \\
{\left[\mathrm{~Pb}(\text { Benzene })_{2} \mathrm{CH}_{4}\left(\mathrm{H}_{2} \mathrm{O}\right)_{2}\right]^{2+} \rightarrow\left[\text { Pb }(\text { Benzene })_{2}\left(\mathrm{H}_{2} \mathrm{O}\right)_{2}\right]^{2+}+\mathrm{CH}_{4}} \\
{\left[\mathrm{~Pb}(\text { Benzene })_{2}\left(\mathrm{CH}_{4}\right)_{3}\left(\mathrm{H}_{2} \mathrm{O}\right)_{2}\right]^{2+} \rightarrow\left[\text { Pb }(\text { Benzene })_{2}\left(\mathrm{H}_{2} \mathrm{O}\right)_{2}\right]^{2+}+3 \mathrm{CH}_{4}(12)} \\
{\left[\mathrm{Pb}(\text { Benzene })_{2}\left(\mathrm{CH}_{4}\right)_{3}\left(\mathrm{H}_{2} \mathrm{O}\right)_{3}\right]^{2+} \rightarrow\left[\mathrm{Pb}(\text { Benzene })_{2}\left(\mathrm{CH}_{4}\right)_{3} \mathrm{H}_{2} \mathrm{O}\right]^{2+}+3 \mathrm{CH}_{4}}
\end{gathered}
$$

The total binding energy is given by Equation (4) while Equation (5) defines the binding energy relative to charge transfer and Equation (6) can best be described as the incremental binding energy reaction. However, Equations (7)-(13) represented electrostatic interaction of lead benzene dication complex ion with methane molecules at various stages of the activation process as identify by the ion peaks. From the thermodynamic point of view the photofragmentation mechanisms of $\left.[\mathrm{Pb} \text { (Benzene })_{2}\right]^{2+}$ leading to the formation of the products are highly feasible and does not necessarily depend on electronic excited state to occur. This is due to the fact that the first ionization energy of lead is lower than that of Benzene $[\mathrm{IE}(\mathrm{Pb})=7.42 \mathrm{eV}$ and IE $(\mathrm{Bz})=9.24 \mathrm{eV}]$ a charge transfer reaction could be spontaneous. Puskar et al. in the application of the pickup technique in association with high-energy electron impact ionization to form complexes in the gas phase between $\mathrm{Pb}^{2+}$ with a wide range of ligands; observed that $\mathrm{Pb}$ dissimilar itself from many other metal dication complexes. The subsequent of collisional activation is that very slight chemical reactivity is demonstrated [17]. Hence such reactions are initiated using the energy difference between $\mathrm{M}^{2+}$ $+\mathrm{e}^{-} \rightarrow \mathrm{M}^{+}$and $\mathrm{L} \rightarrow \mathrm{L}^{+}+\mathrm{e}^{-}$, which normally is $\sim 5 \mathrm{eV}$ and are mostly promoted via charge transfer. The resultant effect of this energy difference is the appearance of $\mathrm{L}^{+}$and the loss of a substantial fraction of the residual ligands as neutral species in the $\mathrm{Pb}^{2+}$ complexes. In most occasions $\mathrm{Pb}^{+}$appears as a charge-transfer product [17].

\section{Theory}

The density functional theory as implemented in Gaussian 09 [21] were used to calculate structures and binding energies of $\left.[\mathrm{Pb} \text { (benzene })_{2}\right]^{2+}$ and lead dication complex ions with methane. The local density approximation (LDA) [22] together with the gradient-corrected exchange of Becke [23] and the correlation correction of Perdew [24] (BVP86) were applied on geometry optimization and 
frequency analysis. Structural minima were verified by the absence of imaginary vibrational modes. These calculations were compared with results calculated using the metahybrid functional of Tao, Perdew, Staroverov, and Scuseria (TPSSh) [25]. A 6-311++G(d,p) basis set was used for all atoms except $\mathrm{Pb}^{2+}$, for which the standard SDD relativistic pseudopotential (ECP78MWB) was used [26]. All energies presented are zero point energy corrected. The two optimised geometries observed on $\left.[\mathrm{Pb} \text { (Benzene) })_{2}\right]^{2+}$ were the $\mathrm{C}_{2 \mathrm{~V}}$ eclipse (Figure 6) and $\mathrm{C}_{2}$ staggered (Figure 7). The resultant effect was that the rings of the sandwich complexes were not parallel with angle of $180^{\circ}$, rather bent hemi-directed geometries with centroid- $\mathrm{Pb}$-centroid angle of $\sim 167^{\circ}$ however, this angle was slightly larger than the $162^{\circ}$ obtained previously [18]. The $\mathrm{Pb}$-Benzene bonds were typically found to be focused all the way through only part of the coordination sphere for lead dication complexes, suggesting possibility of the calculated bent structures being expression of this effect.

From Table 1 it is clear that the total binding energy defined as $\left[\mathrm{Pb}(\text { Benzene })_{2}\right]^{2+}$ $\rightarrow \mathrm{Pb}^{2+}+2 \mathrm{Benzene}$ has the highest calculated binding energy follow by the incremental binding energy, defined as $\left[\mathrm{Pb}(\text { Benzene })_{2}\right]^{2+} \rightarrow[\mathrm{Pb}(\text { Benzene })]^{2+}+$ Benzene, with the calculated binding energy relative to charge transfer defined as $\left.[\mathrm{Pb} \text { (Benzene })_{2}\right]^{2+} \rightarrow[\mathrm{Pb}$ (Benzene $\left.)\right]^{+}+$Benzene $^{+}$recording the lowest. The accessibility of the staggered and eclipsed conformers of $\left[\mathrm{Pb}(\text { benzene })_{2}\right]^{2+}$ in this experiment was demonstrated by the approximately the same calculated binding energy values observed with BVP86 and TPSSH.
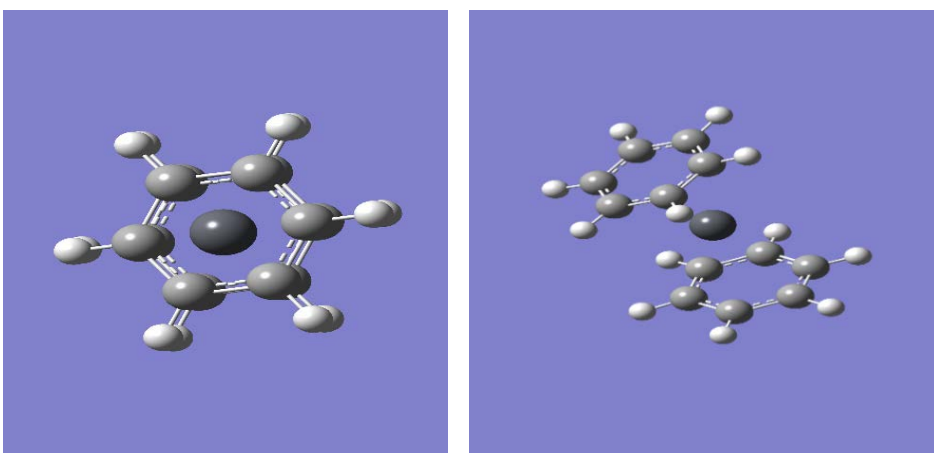

Figure 6. Optimized $C_{2 v}$ using BVP86, 6-311++G(d,p) as basic sets.
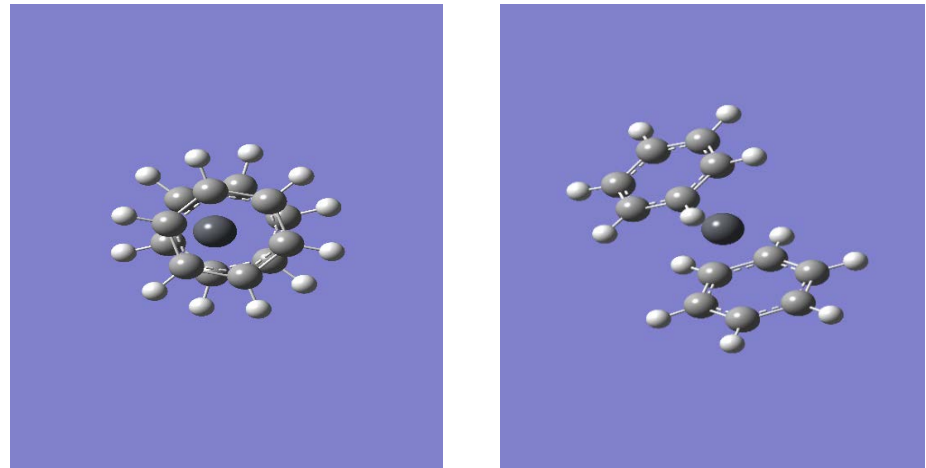

Figure 7. Optimized $\mathrm{C}_{2}$ using BVP86, 6-311++G(d,p) as basic sets. 
Table 1. Binding Energies for the $\mathrm{Pb}^{2+}$ Complexes with respect to various Products formed and Calculated using both BVP86/6311++G(d,p) and TPSSh/6311++G(d,p).

\begin{tabular}{cccc}
\hline \multirow{2}{*}{ Reaction } & Structure & \multicolumn{2}{c}{ Energy/kJ.mol ${ }^{-1}$} \\
\cline { 3 - 4 } & & BVP86 & TPSSh \\
\hline$\left[\mathrm{Pb}(\text { Benzene })_{2}\right]^{2+} \rightarrow \mathrm{Pb}^{2+}+2$ Benzene & $\mathrm{C}_{2 \mathrm{v}}$ : Eclipsed & 641.00 & 641.00 \\
{$\left[\mathrm{~Pb}(\text { Benzene })_{2}\right]^{2+} \rightarrow[\mathrm{Pb}(\text { Benzene })]^{+}+(\text {Benzene })^{+}$} & $\mathrm{C}_{2}$ : Staggered & 641.10 & 641.20 \\
{$\left[\mathrm{~Pb}(\text { Benzene })_{2}\right]^{2+} \rightarrow[\mathrm{Pb}(\text { Benzene })]^{2+}+($ Benzene $)$} & $\mathrm{C}_{2}$ : Staggered & 23.10 & 22.40 \\
{$\left[\mathrm{~Pb}(\text { Benzene })_{2}(\mathrm{Me})\right]^{2+} \rightarrow\left[\mathrm{Pb}(\text { Benzene })_{2}\right]^{2+}+\mathrm{Me}_{2 \mathrm{v}}$ : Eclipsed } & 191.50 & 192.40 \\
{$\left[\mathrm{~Pb}(\text { Benzene })_{2}(\mathrm{Me})_{2}\right]^{2+} \rightarrow[\mathrm{Pb}(\text { Benzene })]^{2+}+2 \mathrm{Me}$} & 191.40 & 192.30 \\
{$\left[\mathrm{~Pb}(\text { Benzene })_{2}(\mathrm{Me})_{2}\right]^{2+} \rightarrow\left[\mathrm{Pb}(\text { Benzene })_{2}(\mathrm{Me})\right]^{2+}+\mathrm{Me}$} & 8.20 & 8.19 \\
{$\left[\mathrm{~Pb}(\text { Benzene })(\mathrm{Me})_{3}\right]^{2+} \rightarrow[\mathrm{Pb}(\text { Benzene })]^{2+}+3 \mathrm{Me}$} & 11.41 & 11.40 \\
{$\left[\mathrm{~Pb}(\text { Benzene })_{2}(\mathrm{Me})\left(\mathrm{H}_{2} \mathrm{O}\right)\right]^{2+} \rightarrow\left[\mathrm{Pb}(\text { Benzene })_{2} \mathrm{H}_{2} \mathrm{O}\right]^{2+}+\mathrm{Me}$} & 3.23 & 3.24 \\
{$\left[\mathrm{~Pb}(\text { Benzene })_{2}\left(\mathrm{H}_{2} \mathrm{O}\right)_{2}(\mathrm{Me})\right]^{2+} \rightarrow\left[\mathrm{Pb}(\text { Benzene })_{2}\left(\mathrm{H}_{2} \mathrm{O}\right)_{2}\right]^{2+}+\mathrm{Me}$} & 128.08 & 128.07 \\
{$\left[\mathrm{~Pb}(\text { Benzene })_{2}\left(\mathrm{H}_{2} \mathrm{O}\right)_{2}(\mathrm{Me})_{3}\right]^{2+} \rightarrow\left[\mathrm{Pb}(\text { Benzene })_{2}\left(\mathrm{H}_{2} \mathrm{O}\right)_{2}\right]^{2+}+3 \mathrm{Me}$} & 298.36 & 298.30 \\
\hline
\end{tabular}

At the initial geometry of $\left[\mathrm{Pb}(\text { Benzene })_{2}\left(\mathrm{CH}_{4}\right)\right]^{2+}$ with methane the benzene-lead-benzene bond was $180^{\circ}$; all the hydrogen-carbon-hydrogen bonds in methane were observed to be $109.50^{\circ}$ and the two benzene-lead-methane angles were observed to be $90^{\circ}$ and $89.79^{\circ}$ for the top and down benzene molecules respectively. However, at the optimised geometry of $\left[\mathrm{Pb}(\text { Benzene })_{2}\left(\mathrm{CH}_{4}\right)\right]^{2+}$ (Figure 8) all the initial angles was observed to be distorted; for instance benzene-lead-benzene bond was distorted from $180^{\circ}$ to $166.01^{\circ}$, the top benzene- $\mathrm{Pb}$-methane bond is distorted to $101.10^{\circ}$ while the down benzene- $\mathrm{Pb}$ methane bond was distorted to $107.49^{\circ}$. The angles of $109.5^{\circ}$ in methane were distorted to $107.11^{\circ}, 108.94^{\circ}, 113.01^{\circ}, 107.10^{\circ}$ with the remaining two angles distorted to equal values of $110.25^{\circ}$.

In order to represent the observed charge separation reaction qualitatively a one-dimensional potential energy curve model was plotted (Figure 9). From the curves, it can be seen that the photo induced charge transfer to give $\left[\mathrm{Pb}\left((\text { Benzene })_{2}\right]^{+}\right.$ and $\mathrm{CH}_{4}^{+}$of $\left[\mathrm{Pb}(\text { Benzene })_{2}\left(\mathrm{CH}_{4}\right)\right]^{2+}$ was also not observed because this reaction was endothermic as evidenced by observing that the repulsive energy curve (blue) lies above the attractive curve (red).

At the optimised geometry of $\left.[\mathrm{Pb} \text { (Benzene })_{2}\left(\mathrm{CH}_{4}\right)\right]^{2+}$ the lead-methane distance (Pb-C) (Figure 9) was $2.24 \AA ̊$ corresponded to $0.114 \mathrm{eV}(11.00 \mathrm{~kJ} / \mathrm{mol}$ in photon energy) on the PEC. Comparing with the calculated DFT of $8.20 \mathrm{~kJ} / \mathrm{mol}$ it was clear that the calculated PEC value was higher by $2.80 \mathrm{~kJ} / \mathrm{mol}$ than calculated DFT value. This difference can be accounted for by the charge differences on the lead metal centre, while calculated charge on the $\mathrm{Pb}$ in the optimised geometry was 1.68 the charge of $\mathrm{Pb}=2$ was considered in the $\mathrm{PEC}$ calculation. 


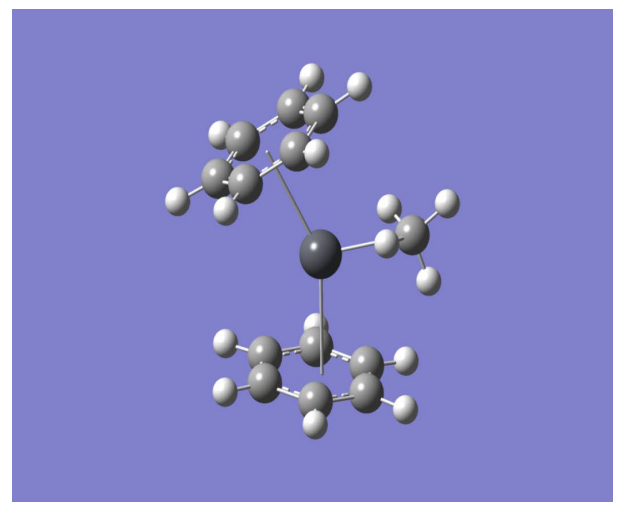

Figure 8. The Optimized geometry of $\left[\mathrm{Pb}(\text { Benzene })_{2}\left(\mathrm{CH}_{4}\right)\right]^{2+}$ at BSVP86/6311++G(d,p) with $\mathrm{C}_{1}$ Symmetry.

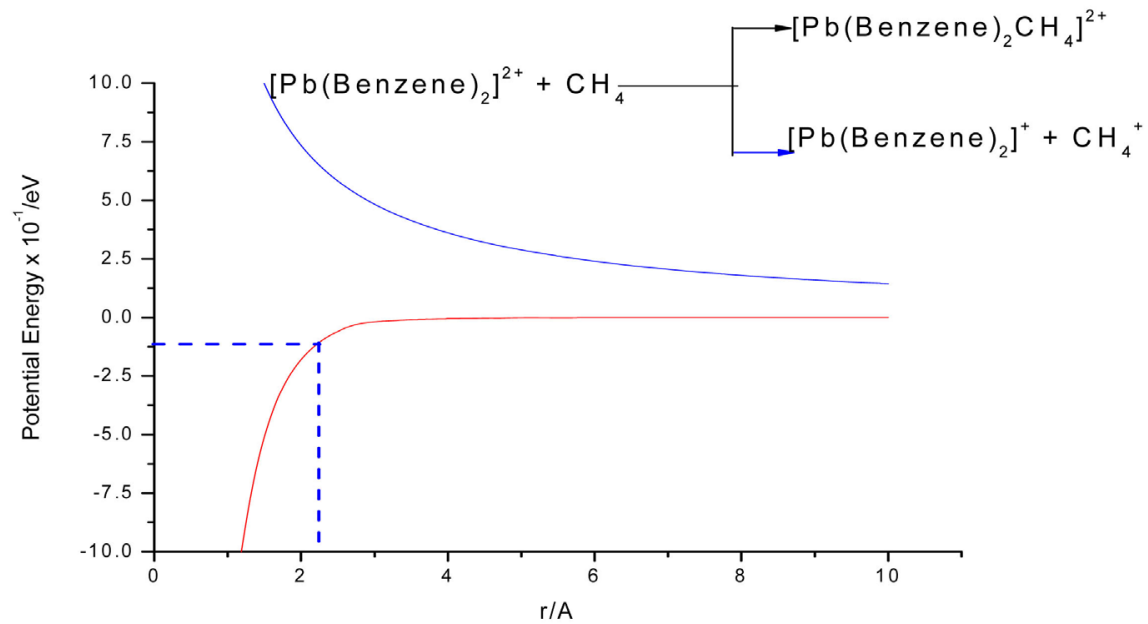

Figure 9. Potential energy curve model showing attractive and repulsive curves of $\left[\mathrm{Pb} \text { (Benzene) }{ }_{2} \mathrm{CH}_{4}\right]^{2+}$.

\section{Conclusions}

The UV spectra of $\left.[\mathrm{Pb} \text { (Benzene })_{2}\right]^{2+}$ complexes have been recorded in the gas phase from ions that have been held and cooled in an ion trap which was then activated successfully with methane molecules at a selected photon energy. Photofragmentation of $\left[\mathrm{Pb}(\text { Benzene })_{2}\right]^{2+}$ complexes yielded $\mathrm{Pb}^{+}$and benzene ${ }^{+}$contrary to the previous work of Ma et al. [18].

The calculated binding energies on the optimised geometry of $\left[\mathrm{Pb}(\text { Benzene })_{2}\right]^{2+}$ revealed that the values obtained were slightly lower than the previous values obtained at same levels of theory of zero point energy probably due to a slightly larger distortion angle observed in the optimised geometry in this current work. The PEC calculated binding energy of methane to lead benzene dication complex ion was approximately $25.45 \%$ higher than the value recorded on DFT; this difference can be accounted for by the charge differences on the lead metal centre. The actual calculated charge on the $\mathrm{Pb}$ in the optimised geometry was 1.68 while the charge of $\mathrm{Pb}=2$ was considered in the PEC calculation. The incremental addition of methane to the metal dication complex revealed approxi- 
mately $39.15 \%$ difference in binding energy between $\left[\mathrm{Pb}(\text { Benzene })_{2}\left(\mathrm{CH}_{4}\right)\right]^{2+}$ and $\left.[\mathrm{Pb} \text { (Benzene })_{2}\left(\mathrm{CH}_{4}\right)_{2}\right]^{2+}$ for the calculated DFT values.

\section{Acknowledgements}

The author would like to thank Prof. Anthony Stace of University of Nottingham School of Chemistry, UK for all the sacrifice and support to see this research through, Dr Lifu Ma of University of Nottingham School of Chemistry for his contributions Prof Hazel Cox of the University of Sussex UK, Computational chemistry Department for the Software and computer time.

\section{Funding}

The author is indebted to British government for granting him "International Excellence Research Award" which made the financial assistance for this research in the Nottingham University UK possible.

\section{Conflicts of Interest}

The author has no conflicts of interest regarding the publication of this paper.

\section{References}

[1] IPCC AR5 WG1 (2013) Climate Change 2013: The Physical Science Basis-Summary for Policymakers. Cambridge University Press, Cambridge.

[2] https://www.esrl.noaa.gov/gmd/ccgg/trends_ch4/

[3] Lunsford, J.H. (2000) Catalytic Conversion of Methane to More Useful Chemicals and Fuels: A Challenge for the 21st Century. Catalysis Today, 63, 165-174. https://doi.org/10.1016/S0920-5861(00)00456-9

[4] Hemberg, S. (2000) Lead Poisoning in a Historical Perspective. American Journal of Industrial Medicine, 38, 244-254. https://doi.org/10.1002/1097-0274(200009)38:3<244::AID-AJIM3>3.0.CO;2-F

[5] Bressler, J., Kim, K., Chakraborti, T. and Goldstein, G. (1999) Molecular Mechanisms of Lead Neurotoxicity. Neurochemical Research, 24, 595-600.

[6] Godwin, H.A. (2001) The Biological Chemistry of Lead. Current Opinion in Chemical Biology, 5, 223-227.

[7] Chisolm, J.J., Mahaffey, K.R. and Aronson, A.L. (1976) Diagnosis and Treatment of Lead Poisoning, MSS Information, New York.

[8] Casas, J.S. (2006) Lead Chemistry, Analytical Aspects, Environmental Impact and Health Effects. Elsevier, Amsterdam.

[9] Stewart, H., Wu, G., Ma, L., Barclay, M., Vieira, A.D., King, A., Cox, H. and Stace, A.J. (2011) Ultraviolet Photofragmentation Spectroscopy of Alkaline Earth Dication Complexes with Pyridine and 4-Picoline (4-Methyl Pyridine). The Journal of Physical Chemistry A, 115, 6948-6960.

[10] Burt, M.B., Decker, S.G.A., Atkins, C.G., Rowsell, M., Peremans, A. and Fridgen, T.D.J. (2011) Structures of Bare and Hydrated $[\mathrm{Pb}(\text { AminoAcid-H })]^{+}$Complexes Using Infrared Multiple Photon Dissociation Spectroscopy. The Journal of Physical Chemistry B, 115, 11506-11518. https://doi.org/10.1021/jp2068655

[11] Firdoussi, A.E., Lafitte, M., Tortajada, J., Kone, O. and Salpin, J.Y. (2007) Characte- 
rization of the Glycosidic Linkage of Underivatized Disaccharides by Interaction with $\mathrm{Pb}(2+)$ Ions. Journal of Mass Spectrometry, 24.

[12] Salpin, J.Y., Guillaumont, S., Ortiz, D.,Tortajada, J. and Maître, P. (2011) Direct Evidence for Tautomerization of the Uracil Moiety within the Pb2+/Uridine-5' Monophosphate Complex: A Combined Tandem Mass Spectrometry and IRMPD Study. Inorganic Chemistry, 50, 7769-7778.

[13] Salpin, J.-Y., MacAleese, L., Chirot, F. and Dugourd, P. (2014) Structure of the $\mathrm{Pb}^{2+}$-Deprotonated dGMP Complex in the Gas Phase: A Combined MS-MS/IRMPD Spectroscopy/Ion Mobility Study. Physical Chemistry Chemical Physics, 16, 14127-14138. https://doi.org/10.1039/c4cp00163j

[14] Singh, H.L. (2016) Synthesis, Spectroscopic and Molecular Studies of Lead(II) Complexes of Schiff Bases Derived from 4-Methoxybenzaldehyde and Amino Acids. Rasayan Journal of Chemistry, 9, 614-626. https://www.researchgate.net/publication/311420546

[15] Salpin, J.-Y. and Tortajada, J.J. (2003) Gas-Phase Reactivity of Lead(II) Ions with d-Glucose. Combined Electrospray Ionization Mass Spectrometry and Theoretical Study. The Journal of Physical Chemistry A, 107, 2943-2953.

[16] Salpin, J.-Y. and Tortajada, J. (2002) Structural Characterization of Hexoses and Pentoses Using Lead Cationization. An Electrospray Ionization and Tandem Mass Spectrometric Study. Journal of Mass Spectrometry, 37.

[17] Puskar, L., Barran, P.E., Duncombe, B.J., Chapman, D. and Stace, A.J. (2005) Gas-Phase Study of the Chemistry and Coordination of Lead(II) in the Presence of Oxygen-, Nitrogen-, Sulfur-, and Phosphorus-Donating Ligands. The Journal of Physical Chemistry A, 109, 273-282.

[18] Ma, L., Takashima, T., Koka, J., Kimber, H.J., Cox, H. and Stace, A.J. (2013) Conformation-Resolved UV Spectra of $\mathrm{Pb}$ (II) Complexes: A Gas Phase Study of the Sandwich Structures $\left.[\mathrm{Pb} \text { (Toluene })_{2}\right]^{2+}$ and $\left.[\mathrm{Pb} \text { (Benzene })_{2}\right]^{2+}$. The Journal of Chemical Physics, 138.

[19] Stace, A.J. (2002) Metal Ion Solvation in the Gas Phase: The Quest for Higher Oxidation States. The Journal of Physical Chemistry A, 106, 7993-8005. https://doi.org/10.1021/jp020694t

[20] Wu, G., Chapman, D. and Stace, A.J. (2007) Trapping and Recording the Collisionand Photo-Induced Fragmentation Patterns of Multiply Charged Metal Complexes in the Gas Phase. International Journal of Mass Spectrometry, 262, 211-219. https://doi.org/10.1016/j.ijms.2006.11.012

[21] Frisch, M.J., Trucks, G.W., Schlegel, H.B., et al. (2009) Gaussian 09, Revision A.02. Gaussian, Inc., Wallingford.

[22] Vosko, S.H., Wilk, L. and Nusair, M. (1980) Accurate Spin-Dependent Electron Liquid Correlation Energies for Local Spin Density Calculations: A Critical Analysis. Canadian Journal of Physics, 58, 1200-1211. https://doi.org/10.1139/p80-159

[23] Becke, A.D. (1988) Density-Functional Exchange-Energy Approximation with Correct Asymptotic Behavior. Physical Review A, 38, 3098. https://doi.org/10.1103/PhysRevA.38.3098

[24] Perdew, J.P. (1986) Density-Functional Approximation for the Correlation Energy of the Inhomogeneous Electron Gas. Physical Review B, 33, 8822. https://doi.org/10.1103/PhysRevB.33.8822

[25] Tao, J., Perdew, J.P., Staroverov, V.N. and Scuseria, G.E. (2003) Climbing the Den- 
sity Functional Ladder: Nonempirical Meta-Generalized Gradient Approximation Designed for Molecules and Solids. Physical Review Letters, 91, Article ID: 146401. https://doi.org/10.1103/PhysRevLett.91.146401

[26] Kuechle, W., Dolg, M., Stoll, H. and Preuss, H. (1991) Molecular Physics, 74, 1245. http://www.theochem.uni-stuttgart.de 